\title{
SUDDEN DEATH SYNDROME CAUSED BY CARDIAC TUMOR
}

\author{
Dusica Petrovic Rodic1, Marko Spasicㄹ, Biljana Popovska Jovicic 3 , Danijela Milosev4, Slobodanka Lj. Mitrovic ${ }^{1}$ \\ IUniversity of Kragujevac, Faculty of Medical Sciences, Department of Pathology, Clinical Centre "Kragujevac", \\ Kragujevac, Serbia \\ 2University of Kragujevac, Faculty of Medical Sciences, Department of Surgery, Clinical Centre "Kragujevac", \\ Kragujevac, Serbia \\ ${ }^{3}$ University of Kragujevac, Faculty of Medical Sciences, Department of Infectious Diseases, Clinical Centre "Kragujevac", \\ Kragujevac, Serbia \\ ${ }^{4}$ Clinical Centre Kragujevac, Department of Pathology, Kragujevac, Serbia
}

\section{SINDROM IZNENADNE SMRTI UZROKOVAN TUMOROM SRCA}

\author{
Dušica Petrović Rodićl, Marko Spasić², Biljana Popovska Jovičić3 , Danijela Milošev, Slobodanka Mitrović1 \\ IUniverzitet u Kragujevcu, Fakultet medicinskih nauka, Služba za patološko-anatomsku dijagnostiku, Klinički centar \\ „Kragujevac“, Kragujevac \\ 2Univerzitet u Kragujevcu, Fakultet medicinskih nauka, Katedra za hirurgiju, Klinički centar „, Kragujevac“, Kragujevac \\ ${ }^{3}$ Univerzitet u Kragujevcu, Fakultet medicinskih nauka, Katedra za infektivne bolesti, Klinički centar „Kragujevac“, \\ Kragujevac \\ ${ }^{4}$ Klinički centar „Kragujevac“, Služba za patološko-anatomsku dijagnostiku, Kragujevac
}

\begin{abstract}
Cardiac tumors are not a common pathology. However, due to their occurrence in the vital organ, they bare an extremely important clinical significance. According to biological behavior, they are divided into 2 groups, primary (benign and malignant), which are less frequent and secondary (metastatic), which are more common. Among all primary benign cardiac tumors, myxoma is the one that occurs most often. A great number of studies indicate that it originates from multipotent mesenchymal cells of the septum of the left atrium. It is due to its localization that some authors consider it potentially malignant. This paper presents a case of cardiac myxoma which is echocardiographically diagnosed in a 34year-old woman who died suddenly, several days before the scheduled surgery. The diagnosis of the disease was confirmed after the autopsy, by a routine haematoxylin-eosin (H\&E) staining method and an additional immunohistochemistry method (IHC). By presenting a rare clinical case, we emphasize the fact that every diagnosed cardiac tumor requires immediate cardiac surgery without delay.
\end{abstract}

Key words: heart neoplasms; myxoma; autopsy.

\section{INTRODUCTION}

Cardiac tumors are relatively rare (1). May be rarely primary and more often secondary. According to the nature of biological behavior, they can be benign and malignant. Most primary cardiac tumors are biologically benign (75\%), and the most common among them (more than $50 \%$ ) are myxomas. Two morphological forms are distinguished: myxoma globosum and myxoma racemosum, depending on whether the surface is smooth or villous. In addition to myxomas, rhabdomyoma, hemangioma, lime, fibroids, etc. may occur in the heart, and of malignant ones, angiosarcoma, rhabdomyosarcoma, leiomyosarcoma and teratoma malignum may occur in the heart as well.

\section{SA ŽETAK}

Tumori srca nisu česta patologija, ali zbog poljavljivanja $u$ vitalnom organu svakako imaju izuzetno važan klinički značaj. Prema biološkom ponašanju dele se u dve grupe, primarne (benigne $i$ maligne), koji su po učestalosti ređi, $i$ sekundarne (metastatske), koji su češći. Od svih primarnih benignih tumora srca, najčešće se javlja miksom. U većem broju studija navodi se da vodi poreklo od multipotentnih mezenhimalnih ćelija septuma leve pretkomore. Upravo zbog lokalizacije pojedini autori ga smatraju potencijalno malignim. U radu je prikazan slucaj miksoma srca ehokardiografski dijagnostikovan kod žene od 34 godine koja je iznenada umrla, nekoliko dana pre zakazane operacije. Dijagnoza oboljenja je potvrđena nakon autopsije, rutinskom hematoksilin \& eosin ( $H \&$ E) metodom bojenja i dodatnom imunohistohemijskom metodom (IHC). Prikazujući redak klinički slučaj, naglašavamo da svaki dijagnostikovan tumor srca zahteva hitnu kardiohiruršku intervenciju, bez odlaganja.

Ključne reči: neoplazma srca; miksom; autopsija.

The symptomatology of myxoma is diverse and the clinical picture is nonspecific, which greatly complicates timely diagnosis. Their detrimental effect, which depends primarily on localization and size, reflects on the function of the myocardium, conduction system and valvular apparatus, disrupts blood flow through the cardiac cavities, with a high risk of the occurrence of systemic i.e. pulmonary embolization and the occurrence of general disorders in the body. Although being biologically primarily benign, cardial myxomas are considered to be "functionally malignant" tumors due to their localization (2). The selected diagnostic procedure is echocardiography (echo). The diagnosis of myxoma is an absolute indication for immediate cardiac surgery. The paper presents a cardiac myxoma localized in the left atrium. 


\section{CASE REVIEW}

A few days prior to admission, a patient, 34-year-old woman, had suffocation and fatigue when making even the minimal effort, which persisted when resting as well. It is important to note that, a few months earlier, the patient was diagnosed with the specific etiology of the change in pulmonary parenchyma by type of tuberculosis (Figure 1). Treatment was initiated with antitubercular therapy and after clinical improvement, she was released for further home treatment.

At admission, the patient was conscious, afebrile, dyspnoic, auscultatory over the lungs right silent breathing to over $2 / 3$ of the lungs, left to $1 / 2$. Cardiac action potential i.e. tachycardia (120/ $\mathrm{min})$, accentuated S2 over PA and S1 on apex. Chest X-ray (CXR): large effusions bilateral, dominant right. Echo registered an effusion in the pericardial sac, but without actual compromise of the right ventricle. The puncture of pleural content $(1200 \mathrm{ml}-$ clear serous punctate) was performed. The echo showed neat cardiac cavities, except for the left atrium in which a non-homogeneous mass of $41 \times 28.5 \mathrm{~mm}$ was observed which proliferates into the left ventricle in diastole. The post-puncture period flowed neatly, CXR was repeated condition got better. From the punctate based on lactate dehydrogenase (LDH) and protein ratio, it was concluded that this is a case of a transudate, which excluded the exacerbation of a specific process in the lungs, so that the patient was indicated for surgical treatment.

In the morning, her condition got worse, the patient was confused, her breathing was difficult and irregular and mydriasis soon occurred. Cardiopulmonary resuscitation was initiated, cardiac arrest was still present and pupils were dilated, followed by an absence of breathing. The final diagnosis was made at an autopsy where a $55 \times 58 \mathrm{~mm}$ cardiac tumor was detected, starting from the middle of the atrial septum with $18 \mathrm{~mm}$ wide and $12 \mathrm{~mm}$ high petiole, filling the left atrium and partially the left ventricle. Macroscopically, the surface of the tumor was villous, greyish-yellow in color, vitreous, gelatinous in consistency. A number of sections were taken for pathohistological analysis from the tumor surface, from
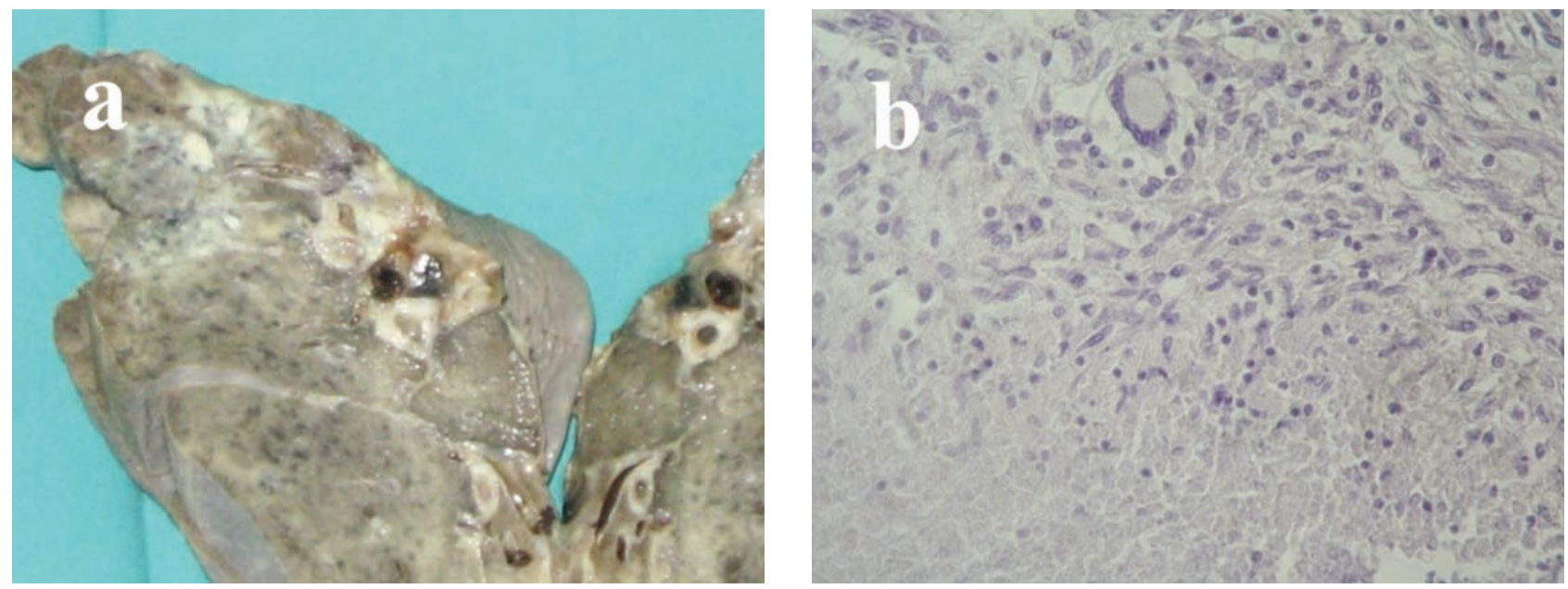

Figure 1. Macroscopic (a) and microscopic image of lung tuberculosis (b, H\&E, x400,original magnification).
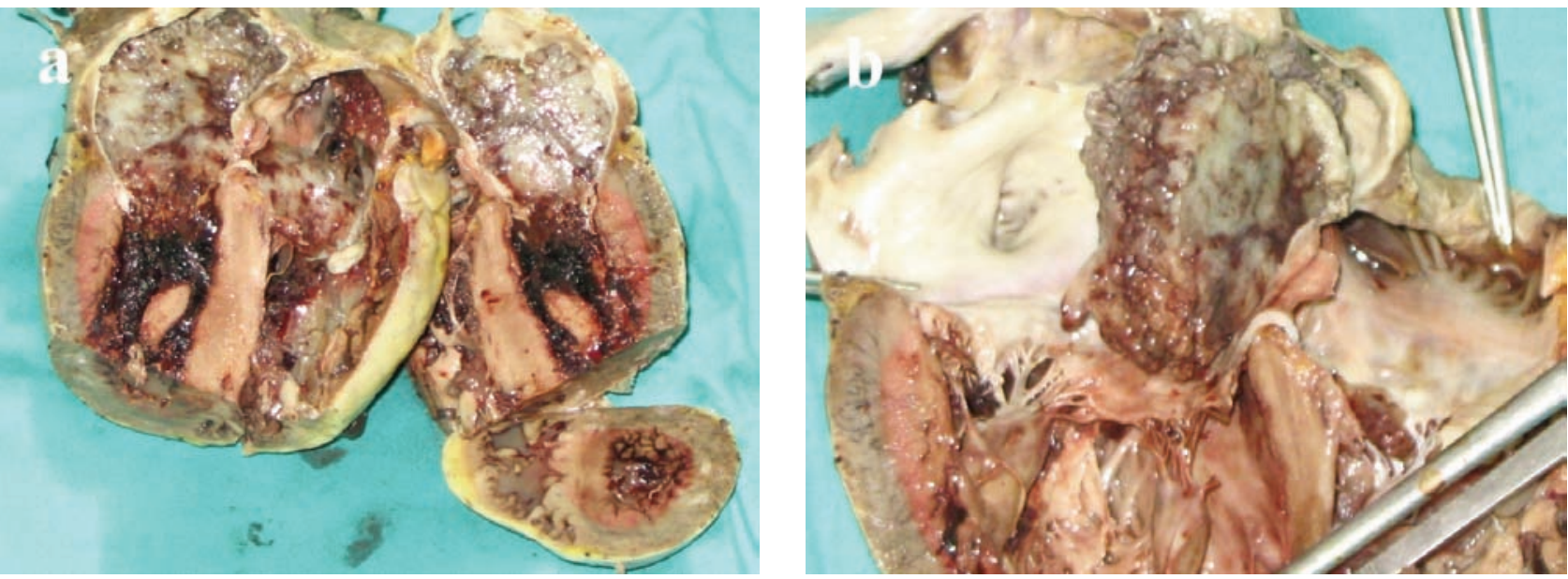

Figure 2. Autopsy image of cardiac myxoma. a) The tumor mass fills the atrium of the heart and prolapses into the chamber b) The tumor was greyish-yellow in color and vitreous luster, surface in a villous, gelatinous in consistency. 
the central part, and from the insertion site, which included a part of the atrial septum as well (Figure 2). Tumor sections were fixed in $4 \%$ formalin solution and embedded in paraffin. Serial tissue sections were fixed on glass, followed by a diagnostic, standard H\&E (Figure 3) staining technique and additional IHC analysis with a panel of 18 antibodies. Tumor cells diffusely expressed: S100, CD34, CD141, partly Vimentin, Actin, CD68, with a low proliferative index Ki-67 which was $<1 \%$. Tumor cells did not express: Desmin, CK7, CK8, E-cadherin, Myogenin, Caldesmon, CD43, CD99, Estrogen receptors and Progesterone, HER-2 (Figures 4 and 5).

\section{DISCUSSION}

The most common cardiac tumor is myxoma. (3). These tumors have aroused interest due to their unique localization (left side of the atrial septum near the fossae ovalis), variable clinical presentation, and undefined histogenesis (4). Although this tumor is of unclear histogenesis, it is considered to be of mixed differentiation: endothelial, neurogenic, fibroblastic,
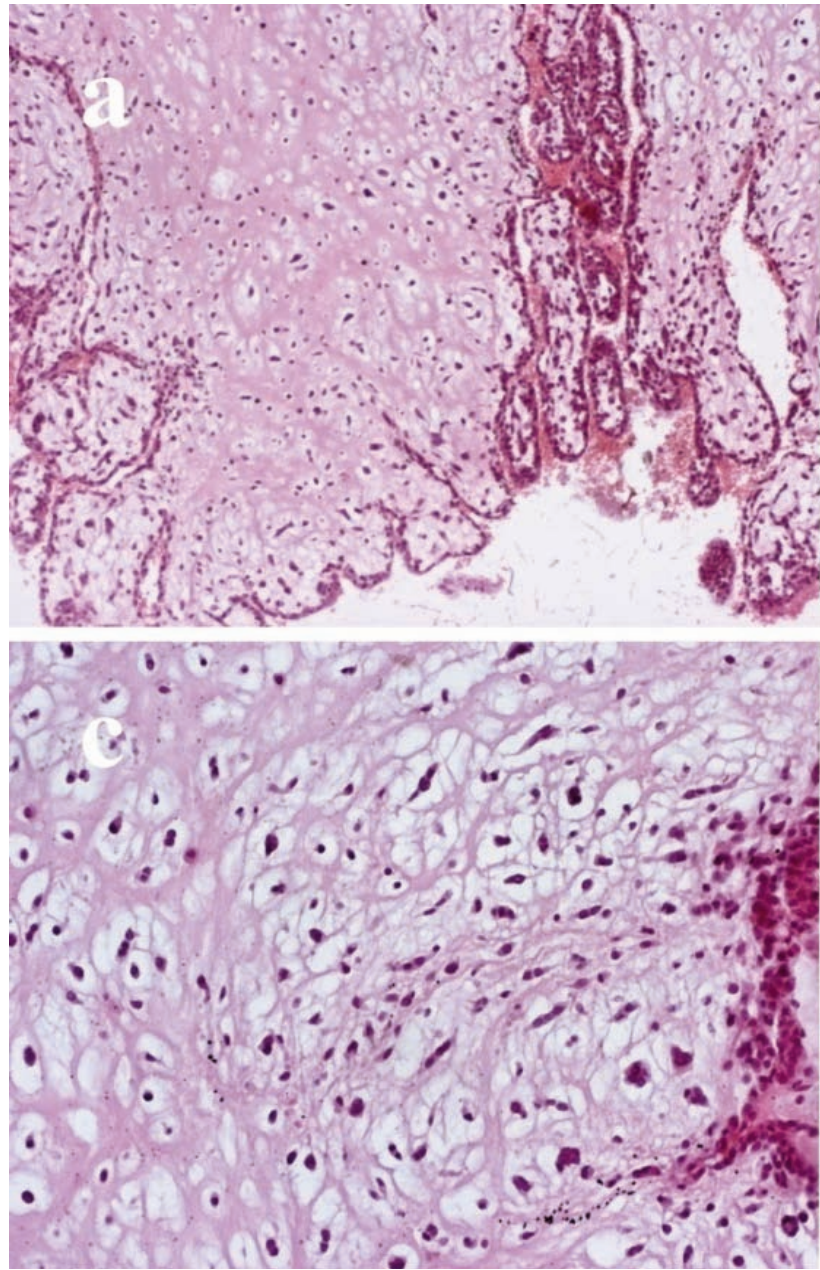

muscular, endocardial, and glandular differentiation has been reported as well. The authors hypothesize that focal cessation of endocardial endothelial maturation occurs (5). It is assumed that this tumor originates from mesenchymal cells, as confirmed by the presence of antibody expression, specific for cardiac cells, as shown in our paper. The resulting immunoprofile indicates mixed differentiation, primarily endothelial and neuroectodermal.

Macroscopically, myxomas are of a polypoid growth mode, with or without petiole and irregularly spherical in shape. The tumor surface can be smooth or villous, greyish-white, yellow and brown in color and the presence of thrombotic masses may be observed on it. Consistency depends on the amount of collagen, and tumor mobility depends on the weight and character of the insertion site (size of the attachment and the petiole). The size of the tumor is within the range between 1-15 cm, usually 5-6 $\mathrm{cm}$. The weight of the tumor is variable. According to the study data, it has ranged from 20 to $175 \mathrm{~g}$. There is a report on the myxoma of the right atrium, weighing $450 \mathrm{~g}(6)$.
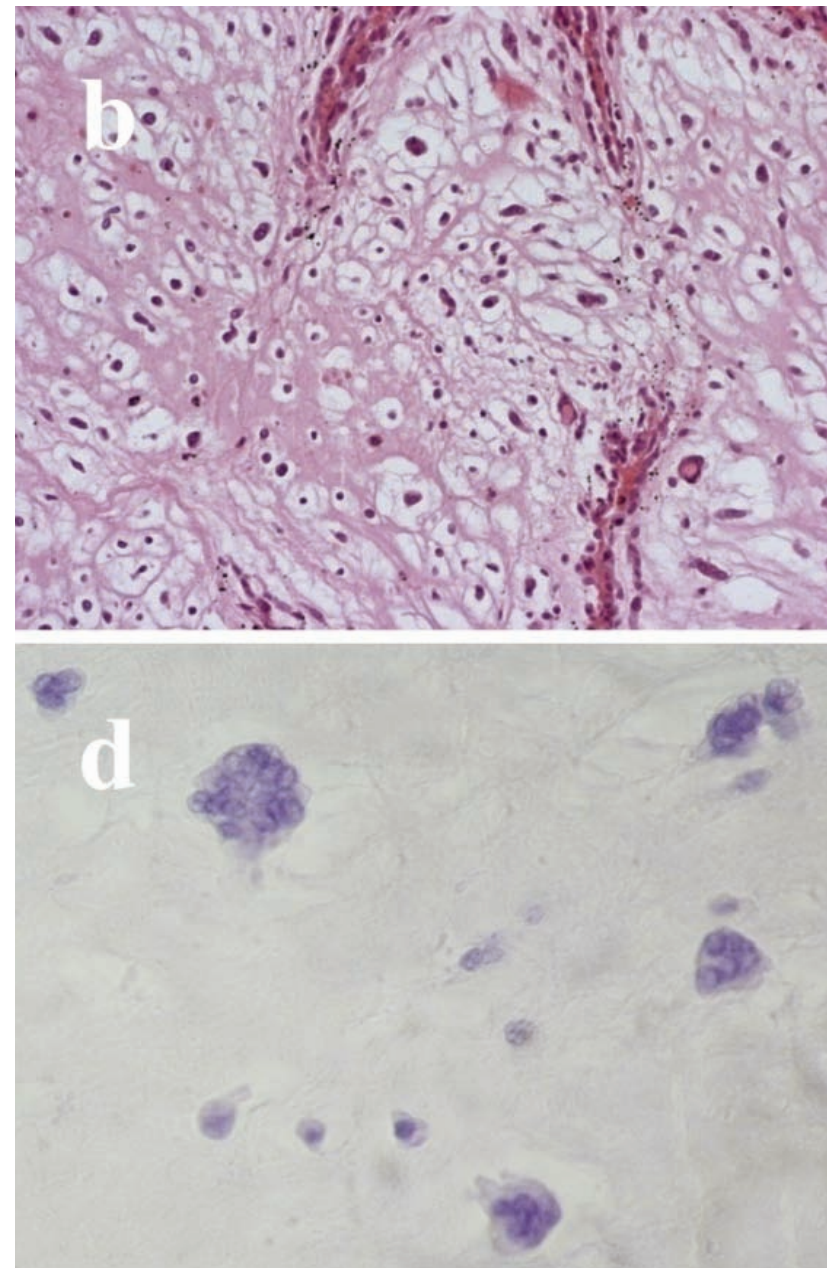

Figure 3. Histological features of a cardiac myxoma: the tumor is composed of a myxoid matrix into which stellate $(a, b, c)$ and multinucleated giant cells (d) are immersed. (H\&E staining technique: $a-x 100, b, c-x 200, d-x 600$, original magnification). 
Histologically, cardiac myxomas are composed of stellate, fusiform, and polygonal cells, immersed in an amorphous myxoid matrix (7). In our paper, we present a cardiac myxoma made from a myxoid matrix that consists of stroma rich in acidic mucopolysaccharides. The matrix contains diffusely distributed polygonal cells with scarce eosinophilic cytoplasm. Cells are grouped individually or in clustered formations, and may be multinucleate, mitoses are absent. These cells take the form of capillary ducts that occasionally interact with the tumor surface. In some cases, large blood vessels - arteries and veins are abundant at the base of the tumor, starting from the subendocardium. Cystic formations and fields of hemorrhage are often observed. Lymphocytes, plasma cells, macrophages, dendritic cells and mastocytes are present in various numbers. Calcification and partial ossification fields can be observed in approximately $10 \%$ of cases as well as glandular elements. The tumor surface is partly covered by a single layer of polygonal cells and partly by endothelial cells.

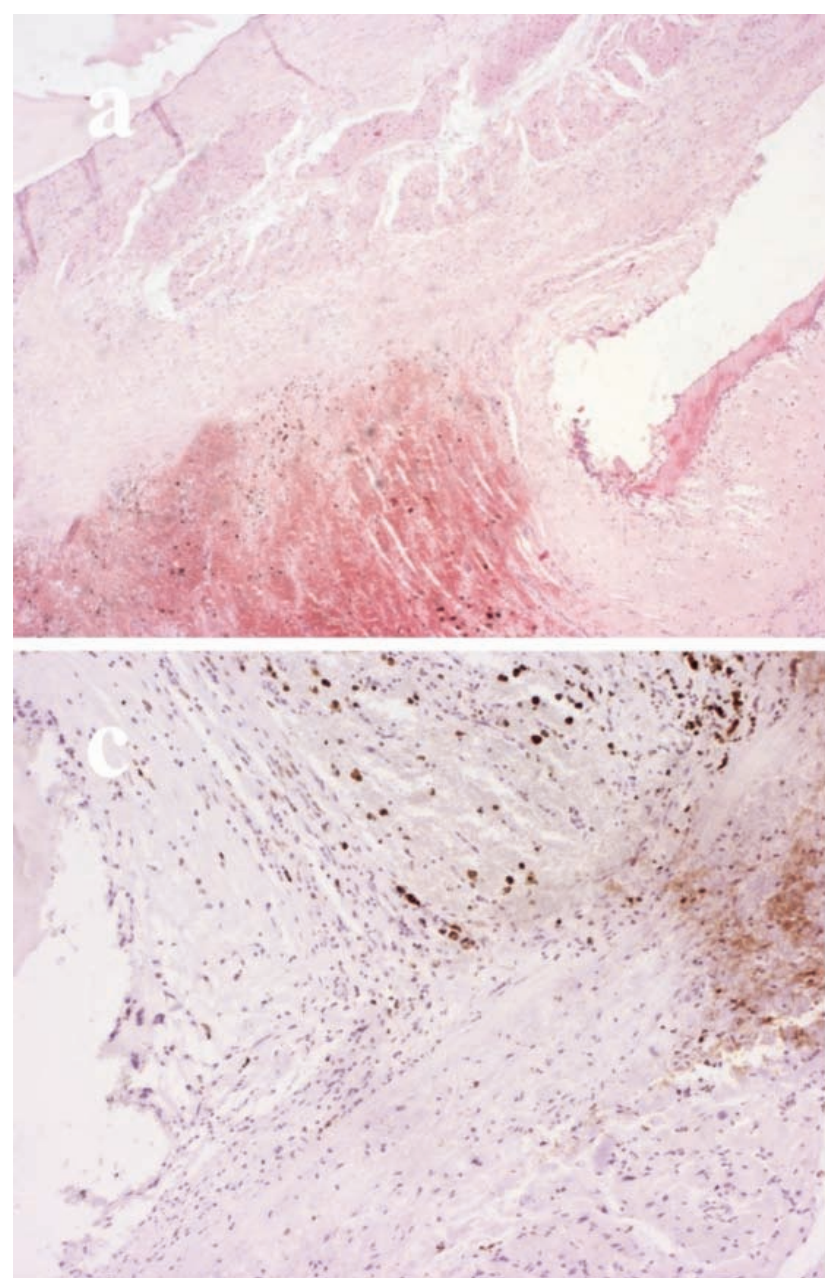

The first complete surgical excision of the left atrial myxoma was done in 1954. Cardiac myxomas are often considered benign lesions (8). According to the literature review, it often happens that they are not diagnosed on time and even remain undiagnosed. In diagnostics, the most important imaging techniques are echo, transoesophageal echocardiography, computed tomography, magnetic resonance imaging and positron emission tomography. Surgical removal of tumor masses from the atrium is relatively easy (9). However, after surgical removal, myxomas reappear causing a dysfunctional heart (10).

Myxomas can occur in all age groups, most commonly between the ages of thirty and sixty. In most published studies, the dominant gender is female. They can occur in two forms: sporadic and familial. People with familial predisposition may have a cardiac myxoma along with a skin myxoma, cutaneous lentiginosis, testicular tumors, breast fibroadenoma and primary micronodular adrenal hyperplasia with Cushing's syndrome. Family studies have indicated that they are inherited autosomal dominantly with a variable phenotype.

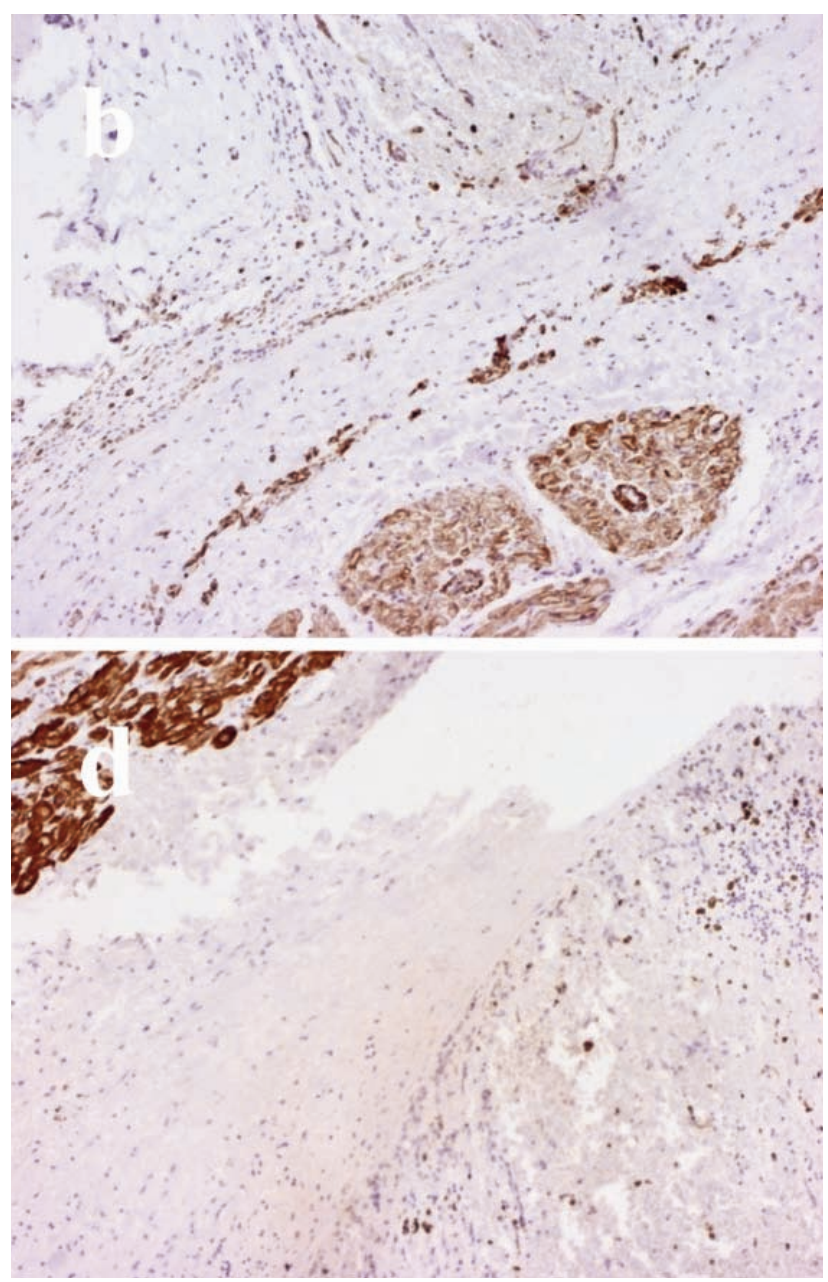

Figure 4. Microscopic image of tumor insertion for the atrial septum. The tumor insertion is permeated with blood (H\&E staining technique: a-x200, original magnification). Cells in the atrial septum express the CD34 (b), but are negative for $S-100$ protein (c) and desmin (d). (IHC staining technique: $b, c, d$-x200, original magnification). 

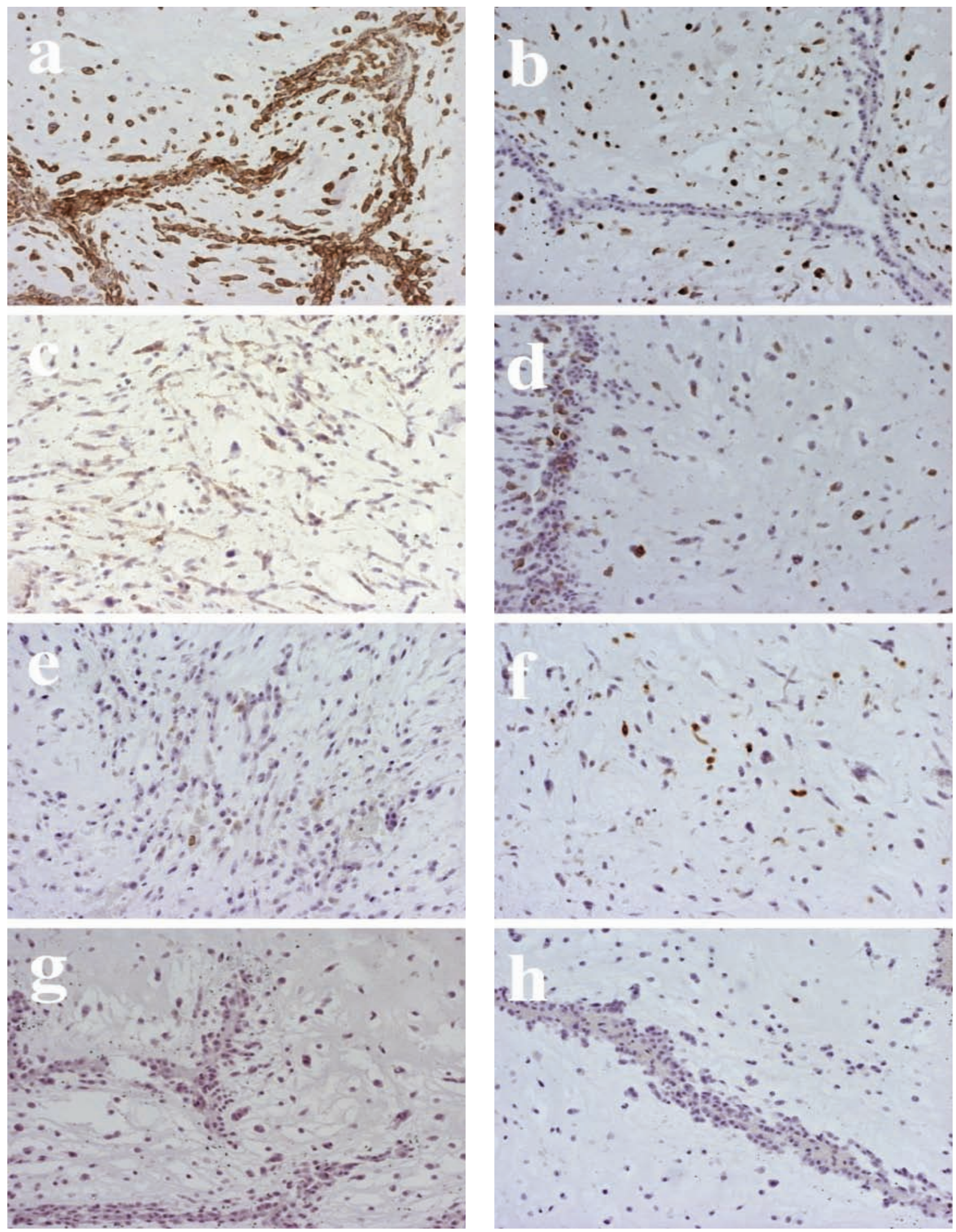

Figure 5. Immunohistochemical features of a cardiac myxoma cells (IHC staining technique: a-h-x200, original magnification). The cells diffusely express CD34 (a), S-100 protein (b) and CD141 (c), moderately express vimentin $(d)$, actin (e) and CD68 (f), weakly express myogenin $(g)$. The Ki67 index is very low, less than 1\% $(h)$. 
Cardiac myxomas are usually formed in the atria, accounting for two thirds $(2 / 3)$ in the left and one third $(1 / 3)$ in the right atrium. They may arise from the septum or from the anterior or posterior wall. Myxomas are rarely multilocular, but there are reports on multiple myxoma in a single atrium, as well as on bilateral myxomas. Tumors that proliferate through the foramen ovale in the opposite direction have been described (10). Myxomas present at the same time in the atrial and pre-atrial cavities have been described as well. Certain tumors have demonstrated nonspecific localizations, most commonly in cases of familial myxomas. Cardiac valve myxomas are extremely rare.

In conclusion, myxomas can occur at all ages, with the highest incidence between the age of thirty and sixty. In most published studies, the dominant gender is female. Myxomas occur in two forms, as sporadic and familial. In addition to standard ultrasound diagnostics, complementary methods include the use of computed tomography and nuclear magnetic resonance imaging. The clinical presentation of myxoma is nonspecific and depends on its size and localization. After surgical removal, the myxomas reappear causing a dysfunctional heart. Every diagnosed cardiac tumor requires immediate cardiac surgery without delay.

\section{REFERENCES}

1. Mercado-Guzman MP, Meléndez-Ramírez G, CastilloCastellon F, Kimura-Hayama E. Evaluation of cardiac tumors by multidetector computed tomography and magnetic resonance imaging.Arch Cardiol Mex 2016; 86: 335-49.
2. Rafajlovski S, Radoje Ilić R, Gligić B, et al. Diagnosis and results of treatment of heart myxoma. Vojnosanit Pregl 2011; 68: 851-5. (in Serbian).

3. Wang H, Li Q, Xue M, Zhao P, Cui J. Cardiac myxoma: a rare case series of 3 patients and a literature review. J Ultrasound Med 2017; 36: 2361-6.

4. Haji K, Nasis A. Radiological characteristics of atrial myxoma in cardiac computed tomography. J Cardiovasc Comput Tomogr 2017; 11: 234-6.

5. Rogov KA, Kaktursky LV, Mikhailova LP. On the histogenesis of cardiac myxoma. Arkh Patol 2018; 80: $3-10$.

6. Lazarides DP. Atrial myxomas. J Cardiovasc Surg 1985; 26: 364. (Abstract).

7. Hernández-Bringas O1, Ortiz-Hidalgo C. Histopathological and immunohistochemical features of cardiac myxomas. Arch Cardiol Mex 2013; 83: 199208.

8. Pacheco-Velázquez SC, Gallardo-Pérez JC, Díaz D, et al. Heart myxoma develops oncogenic and metastatic phenotype. J Cancer Res Clin Oncol 2019; 145: 128395.

9. Wang D, He Y, Zhang R, Zhou Y, Ying K. Pulmonary embolism as the initial manifestatation of right atrial myxoma: a case report and review of the literature. Medicine (Baltimore) 2019; 98: e18386. (doi: 10.1097/MD.0000000000018386).

10. McAllister HA Jr, Fenoglio JJ Jr. Atlas of tumor pathology. 2nd Series. Fascicle 15. Washington DC: Armed Forces Institute of Pathology, 1978. 